\title{
Un caso de influencia virgiliana en el Persiles, la invención de Tile, lugar de origen del héroe
}

\author{
An example of Vergil's influence in the Persiles: \\ the invention of Tile, hero's hometown
}

\author{
Miguel Alarcos Martínez \\ Universidad de Oviedo
}

\begin{abstract}
RESUMEN: Al final del Libro IV del Persiles, Cervantes desvela la identidad y orígenes de los héroes, que hasta entonces han recibido los nombres de Periandro y Auristela. En este contexto, la invención del espacio septentrional de Tile, cuna del protagonista, adquiere una especial relevancia, pues estriba en el imaginario virgiliano de Thule, formulado en los vv. 29-31 de las Geórgicas, I. La clave está en una cita de Virgilio, a la que recurre el ayo Serafido, cuando ilustra su descripción geográfica de Tile. El presente artículo estudia la apropiación cervantina del material citado y su función estética en la novela.
\end{abstract}

Palabras clave: Tile cervantina, ultima Thule virgiliana, reminiscencia / hipotexto, citas literarias, "recontextualización", función estética de la reelaboración, tradición clásica.

ABSTRACT: At the end of Persiles' Book IV, Cervantes discovers identity and origin of the heroes, who have been known till then as Periandro and Auristela. According with this intention, the invention of a Nordic place, as Tile -Hero's hometown-, has a special importance, because of its Vergilian roots on Thule's imaginary, which appears in Georgics, I, vv. 29-31. A Vergil's quotation, which is used by Serafido, when he explains what and where Tile is, gives us the evidence. Our purpose is studying the Cervantine reelaboration of such quotation and its aesthetic function in the romance.

Keywords: Cervantine Tile, Vergil's ultima Thule, reminiscence / hipotext, literary quotations, "context's reelaboration", reelaboration's aesthetic function, classical tradition. 
Conviene señalar, a modo de introducción general, que la poesía virgiliana, y, en especial, la Eneida, constituyen una de las más notables influencias clásicas en la novela póstuma de Cervantes, Historia septentrional. Los trabajos de Persiles y Sigismunda (1617), junto al influjo de la novela griega y de su máximo y más tardío exponente, Heliodoro de Émesa (Hirshig, 1885), autor de la Historia etiópica ${ }^{1}$, traducida en 1587 al castellano por Fernando de Mena (López Estrada, 1954) y recomendada, en cuanto ideal prestigioso de elaboración novelística, por preceptivas literarias, como la Filosofía antigua poética (1596) del Pinciano (Carballo Picazo, 1973; Rico Verdú, 1998).

Además, a diferencia del auge de los novelistas griegos en el Siglo de Oro y de la eclosión de la llamada "novela bizantina", Virgilio para la época de Cervantes, no solo suponía una fuente particularmente apreciada, sino también de sobra conocida, divulgada y actualizada con frecuencia ${ }^{2}$.

Sin embargo, la impronta virgiliana en el Persiles no ha despertado el mismo interés crítico que el género grecobizantino y las Etiópicas, por cuanto configura una parcela minoritaria, habida cuenta de las escasas contribuciones que ha generado $^{3}$, e insuficientemente explorada por los cervantistas especializados

${ }^{1}$ Siendo probablemente el mejor ejemplo, en términos cualitativos, de lo que supuso en la literatura áurea española el fenómeno narrativo y estético de la "novela bizantina", el Persiles también constituye el particular homenaje de Cervantes a la Historia etiópica de Heliodoro, pues así lo explicita en el prólogo a las Novelas ejemplares (1613), cuando anuncia la próxima publicación del Persiles: "tras ellas, si la vida no me deja, te ofrezco los Trabajos de Persiles, libro que se atreve a competir con Eliodoro, si ya por atrevido no sale con las manos en la cabeza".

${ }^{2}$ Cervantes pudo muy bien refrescar sus lecturas escolares de Virgilio con las frecuentes ediciones que circulaban en sus tiempos, así como con el complemento enriquecedor de antologías de extractos y citas (las llamadas Silvas o Polianteas) y, claro está, traducciones, tanto italianas como españolas. Entre éstas últimas, destaca especialmente la versión de la Eneida, realizada por Gregorio Hernández de Velasco en 1555 (Bejarano, 2000), la primera que se hizo del poema épico, reimpresa ocho veces hasta 1574, fecha en que Velasco se decanta por una nueva edición, ahora corregida y ampliada con su versión de las Églogas I y IV. En cuanto a las Bucólicas (o Églogas), Cervantes pudo saber de la traducción por el Brocense de las dos primeras Églogas que, como indica Blecua (2006: 166), debieron ser coetáneas a la edición aumentada de Velasco con sus Églogas $I$ y $I V$. Hay que añadir que en el mismo año de 1574 Juan Fernández de Idiázquez traduce en endecasílabos sueltos las Bucólicas, ofreciendo una edición en cierto modo pedagógica o didáctica, pues contenía notas, explicaciones, argumentos e introducciones; y más adelante, en 1586, otro humanista, Juan de Guzmán publica su versión — también anotada— de la Égloga $X$, entre otros contenidos virgilianos.

${ }^{3}$ Entre las áreas más frecuentes en el estudio crítico de las influencias clásicas en el Persiles, como el molde del género griego y el auge de la novela bizantina en el Siglo de Oro, o bien el cotejo de Heliodoro con Cervantes y sus implicaciones con respecto a la categorización genérica del Persiles, no encuentra acogida el influjo de la literatura latina y, en concreto, el de Virgilio, recibiendo un tratamiento comparable al de Apuleyo, cuando, paradójicamente, esta influencia es casi anecdótica en la Historia Septentrional. De ahí que el marco exegético del presente artículo resulte, a efectos cuantitativos, bastante exiguo: las incursiones de Schevill (1908), reanudadas por Stegman (1971) y el estudio de Armstrong-Roche (2009), contribuciones concentradas en la Eneida y sin más atención a las otras obras que fugaces referencias, a excepción de Armstrong que, por ejemplo, se explaya, como veremos, con la cita de las Geórgicas que desarrollamos en este trabajo. 
en la tradición clásica de la novela cervantina, siendo objeto de análisis parciales e investigaciones tangenciales.

No obstante, podría consignarse como excepción a la regla general la aportación de Barnés (2009), si bien su alcance se restringe al Quijote, pues se trata del primer estudio de conjunto — riguroso y sistemático- que se ha hecho sobre el influjo grecolatino en esta obra y, muy en particular, sobre la lectura cervantina de Virgilio. Ahora bien, es menester precisar que Barnés toma como objeto exclusivo de semejante influencia las desperdigadas alusiones o referencias a la cultura y literatura antiguas que presenta el Quijote, y en modo alguno aborda los materiales propiamente reelaborados, fruto de transformaciones linguiísticas y contextuales de hipotextos, como sí, en cambio, nosotros trataremos de hacer en este artículo y como ya antes hemos hecho en publicaciones recientes (Alarcos, 2011 y 2012: 1195-1208), por lo demás, modestas novedades al estudio de la impronta de Virgilio en la Historia Septentrional.

Por otra parte, la huella de Virgilio, como la de Heliodoro, se distribuyen a lo largo del Persiles de forma desigual: desde Schevill (1906b: 677-704 y 1908: 475-548) se considera que el libro I es el más heliodórico de todos, de la misma manera que el II es el más virgiliano, pero ello no excluye la influencia de Virgilio o su amalgama con Heliodoro en el I, ni en el II la de Heliodoro, entrecruzada o no con Virgilio, como ha apuntado Romero (2004: 47), cuestión ésta que nos ha interesado especialmente y hemos tratado en dos de nuestros trabajos recientes, en un caso, con mayor profundidad y de forma específica (Alarcos, 2011: 315-322), y, en el otro, con no menos minuciosidad, pero a resultas de una exigencia colateral (Alarcos, 2012).

Ahora bien, las reminiscencias virgilianas, al igual que las de las Etiópicas, disminuyen sensiblemente, al pasar a los libros III y IV, sobre todo, en este último, cuyas aventuras ya transcurren en la sacrosanta y bien conocida ciudad eterna, Roma, meta del viaje de los protagonistas, nada que ver con el paisaje septentrional de islas, a menudo imaginarias, de los libros I y II.

Únicamente, a partir de IV, 12, donde se desarrolla el convencional proceso de anagnórisis en torno a los protagonistas, que reclama el desenlace novelesco, emerge con mayor consistencia este doble eje de la tradición clásica en la novela cervantina, si bien incide mucho más Heliodoro.

1. Sin embargo, es aquí, precisamente en IV, 12, donde también se produce el hecho de influencia virgiliano más destacado de todo el libro IV, esto es, la intercalación de una cita de las Geórgicas, en su lengua original ${ }^{4}$, que

${ }^{4}$ La recepción cervantina de las Geórgicas debió estribar en las ediciones vigentes del texto latino y en materiales ancilares, como polianteas o las propias traducciones, ora parciales, ora completas, que comportaban en muchos casos la ventaja de ir ricamente anotadas: entre las ver- 
Cervantes pone en boca del ayo Serafido ${ }^{5}$, y, de la que, además, nos brinda datos precisos de identificación y localización, según nos muestra lo subrayado en el pasaje (pp. 698-699), que transcribimos a continuación ${ }^{6}$ :

También te he dicho cómo en la última parte de Noruega, casi debajo del Polo Ártico, está la isla que se tiene por última en el mundo, (...), cuyo nombre es Tile, a quien Virgilio llamó Tule en aquellos versos que dicen, en el libro 1 Georg.: "ac tua nautae numina sola colant: tibi serviat ultima thule". Que Tule, en griego, es lo mismo que Tile en latín. Esta isla es tan grande, o poco menos, que Inglaterra, rica y abundante de todas las cosas necesarias para la vida humana...

Pues bien, la cita realizada por Cervantes, tras haberla incorporado a la situación argumental que reproduce el pasaje, constituye un material sedimentado de los vv. 29-31 de las Georg. I, "An deus inmensi venias maris ac tua nautae / numina sola colant,/ tibi serviat ultima Thule / teque sibi generum Thethys emat onmibus undis" ("ya acudas como dios del mar inmenso, a ti tan sólo / invoquen los marineros, y cultos rinda Tule / en el confín último del mundo, y te pague Tetis / como yerno suyo con sus ondas todas'), que, a su vez, se engloban en un conjunto más amplio —el texto origen-, esto es, los vv. 2442, reproducidos a continuación:

Tuque adeo, quem nox quae sint habitura deorum concilia, incertum est, urbisne invisere, Caesar, Terrarumque velis curam et te maximus orbis auctorem frugum tempestatumque potentem accipiat, cingens materna tempora myrto, an deus inmensi venias maris ac tua nautae

siones íntegras de las Geórgicas, cabría destacar la ya mentada aportación de Juan de Guzmán, de 1586, cuyos contenidos comprendían esta obra virgiliana, pero también la de Diego López, traducción - con comentarios - en prosa, publicada en Valladolid en 1601 y con once ediciones a sus espaldas hasta 1680, que además incluía la Eneida y las Bucólicas.

${ }^{5}$ Es, por otra parte, el único caso de cita virgiliana en todo el Persiles, en el sentido de 'material citado', de forma explícita y reconocible, sin modificaciones de calado.

${ }^{6}$ Para los pasajes que citamos en el presente artículo, manejamos la edición de Romero (2004), cuya referencia exacta aparecerá en el apartado final de Obras citadas, que precede al de bibliografía; y, en adelante, con vistas a la localización de dichos pasajes en tal edición, incluiremos como únicas referencias las páginas donde se encuentran, encerradas entre paréntesis. Ahora bien, cuando utilicemos a lo largo del trabajo la referencia Romero (2004), especificando alguna página en concreto, estaremos aludiendo a cuestiones críticas o exegéticas, tratadas en su "Estudio Introductorio" que precede a la edición propiamente dicha, o sea, Romero (2004: 11-60).

${ }^{7}$ Una excelente traducción en verso, aunque algo libre, por los condicionamientos métricos, es la de Hernúñez (2003: 181), en el marco de una edición bilingüe: "a ti tan sólo / invoque el nauta, y cultos rinda Tule / al extremo del mundo". En cuanto a la constitución del texto latino, nosotros nos ceñimos a la edición canónica de Virgilio que contiene toda su producción, esto es, la oxoniense de Mynors (1969). 
numina sola colant, tibi serviat ultima Thule.

Teque sibi generum Tethys emat onmibus undis, anne novum tardis sidus te mensibus addas, qua locus Erigonem inter Cherasque sequentes panditur (ipse tibi iam bracchia contrahit ardens Scorpius et caeli iusta plus parte reliquit); quidquid eris (nam te nec sperant Tartara regem nec tibi regnandi veniat iam tam dira cupido, quamvis Elysios miretur Graecia campos nec repetita sequi curet Proserpina matrem), da facilem cursum atque audacibus adnue coeptis ignarosque viae mecum miseratus agrestes ingredere et votis iam nunc adsuesce vocari.

Si cotejamos el material citado por Cervantes con los versos, de los que se extrae la cita, comprobaremos que la reminiscencia consiste en la mera acotación de unas expresiones (ac tua nautae / numina sola colant, tibi serviat ultima Thule), que marcamos en cursiva, y en su reiteración en el texto adoptivo sin modificación alguna, ni en el plano formal ni mucho menos en el del contenido, manteniéndose intacta la "recontextualización", lo que no excluye que se generen mínimas manipulaciones formales y/o semánticas, como hemos visto, transformaciones linguiísticas, pues, sin mayor repercusión para con la literalidad y literariedad hipotextuales, forzadas únicamente por ese nuevo contexto, al que se incorpora el material exógeno.

2. Debemos entonces definir ese contexto originario, en el que se inserta el material hipotextual que Cervantes recontextualiza, adoptándolo como prestigiosa cita de su pasaje de IV, 12.

Por lo que atañe a su contexto más inmediato o específico, los vv. 29-31 de las Geórgicas, de una parte, plantean una eventual analogía del César con una deidad pelágica ("an deus inmensi venias maris") que acapara toda la veneración de los marineros ("tua nautae / numina sola colant"), según se colige de los verbos en subjuntivo venias, colant, serviat y emat, así como de la partícula interrogativa indirecta $a n ; \mathrm{y}$, de otra, enfatizan hiperbólicamente el poderío de Octavio, al generalizar su potestad sobre el conjunto del universo marino, lo que incluye, no solo los mares, sino las masas de tierra, conocidas o inexploradas: de ahí la mención a Thule, que recibe la adjetivación de ultima, constituyéndose en el confín más alejado del mundo, de modo que tampoco este paraje podrá resistirse a la hegemonía de Augusto ("tibi serviat ultima Thule"), espacio legendario que ya en la Antigüedad cuajó como imaginario de lo desconocido, hasta el punto de configurarse como la meta y escenario nuclear de la peculiar novela utópica o fantástica de Antonio Diógenes (posterior a Virgilio, 
probablemente del s. II d. de C.), titulada Las cosas increíbles más allá de Tule (Fusillo, 1990) y, que, por tanto, se difundió en Occidente como tantos otros motivos literarios, atractivos para la cosmovisión del Renacimiento y el Barroco, a lo que contribuyó de forma decisiva las misceláneas geográfico-etnográficas (escritas en latín) de Olao Magno, sobre todo, la Historia de gentibus septentrionalibus (1555), a disposición del público moderno en Monti (2001).

Para colmo, a fin de culminar la equiparación del princeps a la divinidad misma en este ámbito particular de la Naturaleza, no se le ocurre mejor cosa a nuestro vate que hacerlo yerno de Tetis, otorgándole ésta en dote todas las aguas que gobierna ("teque sibi generum Tethys emat omnibus undis").

Ahora, es el texto origen (vv. 24-42) el que nos proporciona el contexto general, consistente en una invocación a Augusto, cuya estructura lingüística básica podríamos representar de esta manera8:

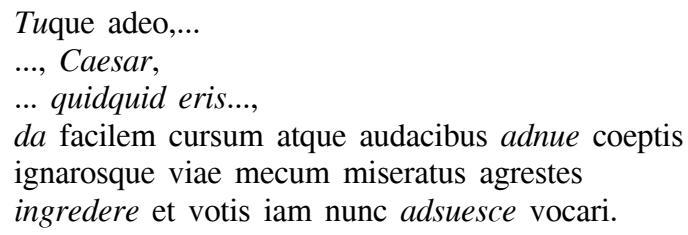

El esquema estructural de la invocación estaría entonces constituido por el pronombre $t u$, el vocativo Caesar, la aposición, a modo de síntesis, quidquid eris, y la sarta de imperativos (da, adnue, ingredere y adsuesce), con las que el poeta trata de granjearse la captatio benevolentiae del César, especialmente, por lo que atañe a sus Geórgicas, como quien pide a los dioses que la cosecha le sea propicia.

Semejante esquema se enriquece en expresividad con la adición de segmentos sintácticos complejos, que desarrollan contenidos, de carácter divinizador, ora a un nivel abstracto (la subordinada de quem... y su expresión más significativa "quae sint habitura deorum / concilia"), ora a un nivel concretísimo, en estudiada progresión y haciendo hincapié en valores morfológicos y léxicos de $2^{\mathrm{a}}$ persona, o sea, las interrogativas indirectas con ne y an: "urbisne invisere / terrarumque velis curam", "te maximus Orbis / auctorem frugum tempestatumque potentem accipiat", "an deus inmensi venias maris ac...tibi...te..." y "anne novum tardis sidus te mensibus addas...".

De este modo, nos enteramos de cuál es el referente del tibi que reproduce fiel Cervantes, en combinación con serviat, en la constatación de que Thule es

\footnotetext{
${ }^{8}$ A fin de facilitar la comprensión de la misma, damos nuestra propia traducción: "y tú, incluso ... / ..., oh César, / ... cualquier cosa que vayas a ser ..., / concédeme fácil curso y favoréceme en mis audaces empresas/ y, compadeciéndote de los labriegos que ignoran su camino, / avanza en mi compañía, y acostúmbrate ya, a partir de ahora, a ser llamado por sus votos”.
} 
el rincón menos conocido del mundo y, por tanto, el más remoto, así como de a quién se refieren los tua numina sola, objeto de la veneración de los nautas: nada menos que a Augusto, el precursor oficial de los emperadores romanos bajo el título eufemístico de Princeps y Pontifex Maximus, aunque, a efectos prácticos, el primero de ellos.

Por el contrario, al examinar el contexto específico del pasaje cervantino, no hay rastro en absoluto de invocaciones, ni menos aún de la divinización del César: sólo quedan como vestigios sus inusitados númenes marinos y la rendición hiperbólica de Tule, pero, claro está, en el ámbito textual de la cita y su sangrado tipográfico; tampoco prevalecen las menciones a Tetis y ni tan siquiera el núcleo expresivo, deus inmanis venias maris; y, por lo que se refiere a la cita en sí, tal y como se ha incorporado al texto adoptivo, aunque mantiene la conjunción copulativa $(a c)$, no ofrece indicio alguno de la correlación an-ne del texto origen, como si tal expresión virgiliana no fuese de ningún modo una interrogativa indirecta compleja.

En su lugar, nos encontramos con lo que parecer ser un diálogo entre personajes, que escucha un afligido Periandro, sin que estos lo sepan, toda una escena de perspectivismo narratológico, donde el héroe se erige en metáfora del lector, en metalector, en suma, como da cuenta el inicio del cap. 12 (pp. $697-$ 698):

Sollozando estaba Periandro, en compañía del manso arroyuelo y de la clara luz de la noche (...), cuando llegó a sus oídos una voz estranjera, que, escuchándola con atención, vio que era en lenguaje de su patria, sin poder distinguir si murmuraba o si cantaba, y la curiosidad le llevó cerca y, cuando lo estuvo, oyó que eran dos personas las que no cantaban ni murmuraban, sino que en plática corriente razonaban. Pero lo que más le admiró fue que hablasen en lengua de Noruega, estando tan apartados della. Acomodóse detrás de un árbol, de tal forma que él y el árbol hacían una misma sombra; (...) y la primera razón que llegó a sus oídos fue:

No tienes, señor, para qué persuadirme de que en dos mitades se parte el día entero en Noruega, porque yo he estado en ella algún tiempo, donde me llevaron mis desgracias, y sé que la mitad del año se lleva la noche, y, la otra mitad, el día. El que esto sea así, yo lo sé; el porqué sea así, ignoro.

Y por lo que concierne al pasaje en sí (pp. 698-699), éste se corresponde con la intervención de uno de los personajes en plática corriente, criado del protagonista, en respuesta a un desconocido, con quien acaba de toparse, que luego sabremos que se llama Rutilio. El ayo, cuyo nombre y oficio tampoco sabemos de entrada, pero que después resultará ser Serafido, sin saber aún quién es Rutilio y qué le une a los peregrinos Periandro y Auristela, le proporciona una imagen completa de Noruega y sus aledaños, en base a una descripción geográfica del mundo septentrional o nórdico (la última parte de Norue- 
$g a)$, que pasa por ser el imaginario espacial de lo desconocido en la concepción barroca, la fascinación preferente de lo exótico en esta época9

A lo que respondió:

Si llegamos a Roma, con una esfera te haré tocar con la mano la causa dese maravilloso efeto, tan natural en aquel clima como lo es en éste ser el día y la noche de venticuatro horas. También te he dicho cómo en la última parte de Noruega, casi debajo del Polo Ártico, está la isla que se tiene por última en el mundo, a lo menos por aquella parte, cuyo nombre es Tile, a quien Virgilio llamó Tule en aquellos versos que dicen, en el libro 1 Georg.: "ac tua nautae numina sola colant: tibi serviat ultima thule". Que Tule, en griego, es lo mismo que Tile en latín (pp. 697-698).

En sus explicaciones cartográficas, el culto fámulo singulariza, en primer término, una isla, de gran tamaño, llamada Tile, definiéndola como "la isla que se tiene por última en el mundo", y, como si pretendiera dar verosimilitud y plasticidad a semejante descripción, la identifica con la Thule mencionada por Virgilio, agregando, luego, que la divergencia de nombres es lo de menos, porque "Tule, en griego, es lo mismo que Tile en latín" ${ }^{10 " . ~}$

\footnotetext{
${ }^{9}$ Esta cuestión, y su reflejo en el Persiles, ha sido tratada con todo rigor y profundidad por Lozano Renieblas (1998) en tres capítulos magistrales que nos gustaría singularizar: "La novedad del septentrión" (pp. 85-89), "La geografía septentrional" (pp. 90-91) y "El inicio del viaje: Tule y Frislandia" (pp. 92-97). En estrecha relación con el asunto, no debemos soslayar la doble concepción de lo exótico en la Antigüedad y de qué modo este hecho resulta significativo para calibrar el grado de implicación cervantina en el resurgimiento y recreación del modelo, esto es, la novela griega, pues, como bien señala Renieblas (1998: 86), "esta vasta extensión geográfica resulta novedosa si la comparamos con sus homólogos de género y, al mismo tiempo, marca la trayectoria que habrían de seguir otros cultivadores de la novela de aventuras en el XVII como Juan Enríquez de Zúñiga o Enríquez Suárez de Mendoza. Las novelas grecobizantinas (a excepción de Las maravillas más allá de Tule de Antonio Diógenes) situaron sus aventuras en el Mediterráneo. Cervantes lo sabía muy bien, como muestra el final del Persiles", por lo que "El Persiles, en cambio, adecúa la geografía a los parámetros conocido-desconocido de su época, repartiendo el escenario del Persiles entre la Europa septentrional - mundo desconocido- y la meridional - mundo conocido-". Para una mayor ampliación de contenidos sobre los orígenes y testimonios literarios del imaginario septentrional — anteriores o posteriores a la Tule virgiliana-, e incluso para profundizar en aquellos otros, de índole geográfica y viajera, remitimos a la magnífica síntesis de Gómez Espelosín (2005: 134-145) y a su rico aparato de notas y referencias a diversos autores clásicos y tardíos.

${ }^{10}$ En efecto, no iba nada descaminado Cervantes, porque la grafía "u", impuesta por la transliteración al castellano, en realidad transcribe la ýpsulon original del topónimo en griego, con un sonido semejante a la /i/ latina, o, cuando menos, asimilable, de manera que Tile vendría a ser la latinización de Tule y, como tal, ya se hallaba extendida en tiempos de Cervantes: por ejemplo, Olao Magno (1490-1557), humanista sueco y obispo de Uppsala, muy célebre por su divulgación de la geografía y etnografía septentrionales, ya utiliza el nombre de Tile, por Tule, en su Carta marina et descriptio septemtrionalium terrarum, publicada en 1539 (Lafréry, 1572: disponible en el World Digital Library que presenta un ejemplar de la Biblioteca Nacional de Suecia), tanto en sus explicaciones como en las ilustraciones cartográficas que enriquecen su compendio. Por otra parte, el hecho de que el Obispo de Uppsala se adelantara a Cervantes en el uso del término Tile
} 
3. Luego, la recontextualización cervantina, aparte de las omisiones aducidas, sólo rescata del contexto primigenio un estrato tan esencial como jugoso: la caracterización virgiliana de Thule, el alcance expresivo del adjetivo ultima, $\mathrm{y}$, de fondo, la fama proverbial de ese espacio ignoto, en suma, el tópico o lugar común; de hecho, en lo que constituye el engarce del texto adoptivo con la cita virgiliana, se detecta una paráfrasis, por amplificatio formal, de los sintagmas citados ultima Thule, esto es, la isla que se tiene por 'última' en el mundo, es decir, casi una traducción dilatada de esos elementos hipotextuales.

Y no solo recupera esos constituyentes contextuales, sino que los subraya, al propugnarse un paralelismo contundente entre el espacio imaginario, inventado por Cervantes (Tile) y la región recóndita evocada con concisión por Virgilio (Tule), paralelismo que desemboca en notoria equivalencia, donde la onomástica diferencial se reduce a mera sinonimia de topónimos. Y es más: se enriquece con su integración en el discurso de un personaje, que exhibe su erudición geográfica, al reforzarla con la autoridad y prestigio de los antiguos.

Los demás componentes contextuales, lejos de eliminarse drásticamente, como cabría pensar con la lectura sola del pasaje, se transfiguran, adquiriendo nuevos matices de significación, que únicamente pueden aquilatarse, al echar una ojeada al contexto general del capítulo 12, que Cervantes encabeza con el enunciado donde se dice quién eran Periandro y Auristela, contexto que se delimita con exactitud, bien que se miren los derroteros temáticos que sigue el discurso del solícito ayo Serafido (pp. 699-703):

De Tile es rey y señor Maximino, hijo de la reina Eustoquia, cuyo padre no ha muchos meses que pasó desta a mejor vida, el cual dejó dos hijos, que el uno es Maximino que te he dicho, que es el heredero del reino, y, el otro, un generoso mozo llamado Persiles, rico de los bienes de la naturaleza sobre todo estremo y querido de su madre sobre todo encarecimiento. Y no sé yo con cuál poderte encarecer las virtudes deste Persiles, y, así, quédense en su punto, que no será bien que con mi corto ingenio las menoscabe. (...) Eusebia, reina de Frislandia, tenía dos hijas de estremada hermosura, principalmente la mayor, llamada Sigismunda (...), donde naturaleza cifró toda la hermosura que por todas las partes de la tierra tiene repartida; a la cual, (...), tomando ocasión de que la querían hacer guerra ciertos enemigos suyos, la envió a Tile (...), puesto que yo para mí tengo que no fue ésta la ocasión principal de envialla, sino para que el príncipe Maximino se enamorase della y la recibiese por su esposa (...) La cual, a la sazón que llegó a Tile, no estaba en la isla Maximino, a quien su madre la reina envió el retrato de la doncella y la embajada de su madre, y él respondió que la regalasen y la guardasen para su esposa; respuesta que sirvió de flecha que atravesó las

no resta originalidad a la reelaboración cervantina de la Tule de Virgilio, puesto que el mérito de Cervantes no radica en la invención onomástica, sino en la configuración de un espacio ficcional verosímil, sobre la base del nórdico finis terrae virgiliano. 
entrañas de mi hijo Persiles (...). Desde que la oyó, no supo oir cosas de su gusto, perdió los bríos de su juventud y, finalmente, (...), vino a perder la salud y a entregarse en los brazos de la desesperación de ella. (...) Abrazóla la reina, contó su respuesta a Persiles y, entre los dos, concertaron que se ausentasen de la isla antes que su hermano viniese, a quien darían por disculpa, cuando no la hallase, que había hecho voto de venir a Roma a enterarse en ella de la fe católica, que en aquellas partes septentrionales andaba algo de quiebra, jurándole primero Persiles que en ninguna manera iría en dicho ni hecho contra su honestidad...

La ojeada nos lleva a comprobar que se ha singularizado la ínsula Tile, porque ésta constituye un espacio novelesco esencial, en cuanto patria originaria del héroe Periandro y punto de partida del viaje emprendido junto con su amada Auristela hasta Roma; y, por lo tanto, su existencia no se señala, ni tan siquiera su ubicación geográfica, hasta IV, 12, es decir, hasta bien entrado el final de la novela, cuando ya se han acumulado dosis más que suficientes de suspense y perplejidad, en un momento narrativo crucial, que entronca con las convenciones del género grecobizantino, puesto que se desvelan los orígenes de los protagonistas, así como el vínculo entre ambos, desechándose absolutamente su fingida hermandad, e incluso salen a la luz sus verdaderos nombres de pila, o sea, Persiles y Sigismunda, por lo que se legitima como apócrifa la onomástica Periandro-Auristela.

Por lo tanto, los valores semánticos relativos a la divinización de Augusto, difuminados en la articulación contextual de la cita, o, en otras palabras, las referencias latentes en la veneración de los marineros y hasta en la servidumbre de Tule hacia alguien en situación dominante, no se vacían de sentido, con la reelaboración del contexto virgiliano: de un lado, Tule pasa a configurarse como una tierra existente en los mapas, cuyo nombre real o verídico sería Tile, subordinada al gobierno de un rey, si bien no carece del halo misterioso y exótico que rodea a los parajes del gélido y alejado Septentrión, y, en consecuencia, la concepción hiperbólica e hipotética del texto origen se desvanece por completo, deshecha, entre otras cosas, con la afirmación del Serafido y el crédito que le concede a la expresión poética de Virgilio; y, de otro, la caracterización ideal de Augusto se incorpora, en sugerente eco, al hasta entonces desconocido perfil de Periandro - ahora Persiles_- que resulta ser oriundo de la ya no tan fabulosa Tule (o Tile), hijo y hermano de reyes, colmado de virtudes en extremo, y divinizado, en ciertas ocasiones, junto con su Sigismunda, a lo largo de la Historia septentrional, además de ser objeto de veneración, al mando de un bajel, por sus marineros, en las gestas del libro II, surgiendo, pues, un nuevo Augusto, donde los encarecimientos se quedan cortos, porque la realidad es tan extraordinaria que supera toda hipérbole.

4. La funcionalidad estética de la cita no se agota en un mero prurito de exhibición cultural o libresca, en boga en los Siglos de Oro, que proporcionaba 
auctoritas, prestigio y ornato a la prosa de los escritores, sino que revela una intencionalidad mucho más compleja, y una aspiración calculada y en absoluto tangencial: fundamenta la versión cervantina del tópico espacial y legitima el imaginario septentrional de la ficción, de principio a fin; propicia la articulación del motivo convencional de la anagnórisis, y, a su vez, el desarrollo de éste, a lo largo de IV, 12; y, sobre todo, nutre de sentido alegórico a la reminiscencia ac tua nautae / numina sola colant: tibi serviat ultima Thule, contribuyendo a la creación de esas transposiciones simbólicas o paralelismos.

Llegados a este punto, cabe comentar el punto de vista de ArmstrongRoche (2009), por diferente al nuestro, sobre todo, por lo que atañe a su interpretación de tales paralelismos entre el territorio conquistado de Thule y la Tile de Periandro/Persiles: así pues, para Armstrong (2009: 70) la Tile cervantina "should be read as an inversión of Vergil's scenario", de manera que

Persiles in turn looks upon Rome as both an exotic finis terrae and ostensibly (for a Catholic) a spiritual home. And yet in Rome, as we shall see, Persiles (Periandro) and Sigismunda (Auristela) turn the spiritual tables and show themselves to be in possession of the better part of Christianity, giving Romans a lesson in the religion for which they are institutional custodians.

Por consiguiente, la exégesis propuesta por Roche vendría a desbaratar toda identificación entre la Tile de Cervantes y la Tule virgiliana, e, igualmente, la descodificación de Periandro como transposición simbólica de un Augusto, que no solo ejerce su dominio sobre el finis terrae, sino que incluso es oriundo de la ultima Thule y sucederá a su hermano Maximino como monarca del septentrional reino-límite.

Por si todo ello no fuera convincente, Roche aduce que la tradición temática de Tule, iniciada, por así decirlo, por Virgilio, contó entre sus emuladores posteriores con la variante antitética del tópico, elaborada por Séneca en su tragedia Medea (Cleasby, 1907; y García Yebra, 1982), según se colige de II, vv. 375-379:

Venient annis saecula seris, quibus Oceanus vincula rerum laxet et ingens pateat tellus Tethysque novos detegat orbes nec sit terris ultima Thule ${ }^{11}$

${ }^{11} \mathrm{Si}$ bien se mira, el verso subrayado es, efectivamente, una reminiscencia del hipotexto virgiliano... tibi serviat ultima Thule..., dado que, con unas pocas sustituciones léxicas - los verbos- $-\mathrm{y}$ el cambio de la modalidad afirmativa a la negativa, el adjetivo ultima del texto origen, preservado por Séneca en su reelaboración, adquiere un sentido nuevo, y, además, totalmente contrario al mensaje poético expresado por Virgilio: 'Tule ya no será la última de entre las tierras conocidas' y, por ende, no cabrá calificarla, siquiera proverbialmente, con semejante adjetiva- 
La interpretación, en conjunto, siendo originalísima, nos parece demasiado rebuscada, porque, aunque Cervantes juega con todas las perspectivas posibles (la heroica, la de los demás personajes y la del lector de la época), retroalimentando su representación irónica de la realidad y su velada crítica o sugerente relativismo, ello no implica que el heroísmo de Periandro y Auristela, y su viaje desde Tile a Roma, tenga que responder a una lectura irónica, jerarquizada por los conflictos religiosos y políticos del contexto epocal, ni mucho menos lleva a superar la analogía entre Tile y Tule que traza claramente Serafido, con complicados juegos ironizantes y desplazamientos perspectivistas, derivados de un cierto afán ideologizador contestatario, que Roche se empeña en ver a toda costa en el Persiles y que parece más propio de la crítica de la posmodernidad que del ingenio cervantino.

Y, por último, como cualquier material reelaborado, posee unos efectos de descodificación, de cara al lector, de forma que éste reconoce los cambios operados en uno y otro contexto, reconstruyendo la Tile de Periandro como una Tule rendida a Augusto, de forma natural y verosímil, sin loas invocatorias ni subjuntivos inciertos.

Este postrer aspecto funcional queda magníficamente ejemplificado con las tres anagnórisis paulatinas que desarrolla el discurso del presunto cartógrafo: una primera, automática, la del propio lector, que completa su imagen de Tile con la sede de un reino desconocido, la figura del rey Maximino, y un verdadero hermano que se fuga con su prometida, a instancias de su madre Eustoquia, esto es, Persiles-Periandro; la segunda, la del propio héroe, cuando nos identifica, en un aparte del narrador, quiénes son los que conversan tan distendidamente (pp. 702-703),

que, puesto que el amor que le tengo, por haber sido su ayo y criádole desde niño, me pudiera llevar a decir mucho, todavía será mejor callar, por no quedar corto". Esto escuchaba Periandro y luego cayó en la cuenta que el que le alababa no podía ser otro que Serafido, un ayo suyo, y que, asimismo, el que le escuchaba era Rutilio, según la voz y las palabras que de cuando en cuando respondía (...) y más, cuando Serafido, que era el mismo que había imaginado, Periandro oyó que dijo: "Eusebia, reina de Frislanda..."

de manera que descubrimos a su ayo Serafido como el artífice de la ecuación Tile $=$ Tule, un criado, pues, que ha leído a Virgilio; y la tercera, la del interlocutor del ayo, esto es, Rutilio, quien tiende un puente perfecto entre el arran-

ción. En este sentido, la interpretación de Armstrong, que parecería fundamentarse en la concepción senequiana, al estimar que ésta estaría muy próxima a la versión cervantina, llevaría a otras consecuencias, es decir, el autor de la Medea habría servido de modelo principal a Cervantes, relegándose entonces a un paradigma secundario el de las Geórgicas, pese a que la cita del Persiles corresponde a Virgilio, y no precisamente al hispano-cordobés. 
que in medias res de la ficción y el desenlace, con sus oportunas aclaraciones, al ligar estrechamente a Persiles y Sigismunda con Periandro y Auristela, "que ha muchos días que los conozco, en cuya compañía he pasado muchos trabajos”, las fatigas del itinerario nórdico por los libros I-II como miembro del hermoso escuadrón de peregrinos (pp. 704-705, final del cap.),

Yo, desde Lisboa, donde me desembarqué, traigo noticias de Persiles y Sigismunda, porque no pueden ser otros que una peregrina y un peregrino de quien la fama viene pregonando tan grande estruendo de hermosura, que, si no son Persiles y Sigismunda, deben de ser ángeles humanados. Si, como los nombras — respondió el que escuchaba a Serafido- Persiles y Sigismunda, los nombraras Periandro y Auristela, pudiera darte nueva certísima dellos, porque ha muchos días que los conozco, en cuya compañía he pasado muchos trabajos. Y luego le comenzó a contar los de la isla bárbara, con otros algunos, en tanto que venía el día, y en tanto que Periandro, porque allí no le hallasen, los dejó solos.

Esta forma o mecanismo de reconocimiento, en última instancia, supone soldar con solidez, no solo la equivalencia Tile-Tule, sino también el paralelismo entre el divinizado César, al que se refieren los acusativos tua numina sola y el dativo tibi, y el virtuoso príncipe de Tile, que sucederá luego a Maximino como soberano, consolidándose como realidad innegable — por arte de la verosimilitud novelesca - lo que en Virgilio es una mera posibilidad hiperbólica del poderío augústeo, esto es, un paraje conjetural en el extremo del mundo, invocado por la imaginación mítica y literaria.

\section{OBRAS CITADAS}

Cervantes, Miguel de (2001 [1613]): Novelas ejemplares, Jorge García López (ed.), Barcelona, Crítica.

Cervantes, Miguel de (2004 [1617]): Los trabajos de Persiles y Sigismunda, Carlos Romero Muñoz (ed.), $5^{\text {a }}$ ed., Madrid, Cátedra.

Cervantes, Miguel de (2006 [1605-1615]): Don Quijote de la Mancha, Alberto Blecua (ed.), Madrid, Espasa-Calpe.

Diogene, Antonio (1990): Le incredibili avventure al di là di Tule, Andreas Schottus (ed. bilingüe: texto griego y trad. latina); Massimo Fusillo (trad. al italiano), Palermo, Sellerio editore.

Erotici Scriptores Graeci (1885 [1856]): Opera, W. A. Hirschig (ed. bilingüe: texto griego y trad. latina), Didot, Paris.

Heliodoro de Émesa (1954 [1587]): Historia etiópica de los amores de Teágenes y Cariclea, traducida en romance por Fernando de Mena, Francisco López Estrada (ed.), Madrid, Biblioteca Selecta de Clásicos Españoles, II, XIV.

López Pinciano, Alonso (1973 [1596]): Philosophía antigua poética, Alfredo Carballo Picazo (ed.), Madrid, Instituto Miguel de Cervantes de Filología Hispánica.

López Pinciano, Alonso (1998): Obras completas, I: Philosophía antigua poética. José Rico Verdú (ed.), Madrid, Turner. 
Magno, Olao (1572 [1539]): Carta marina et Descriptio septemtrionalium terrarum, A. Lafréry (ed.), Rome [World Digital Library: digitalización del ejemplar de la Biblioteca Nacional de Suecia].

Magno, Olao (2001 [1555]): Storia dei popoli settentrionali. Usi, costumi, credenze, Giancarlo Monti (ed. y trad.), Milano, BUR Classici.

Séneca, Lucio Anneo (1907): Medea, Harold Loomis Cleasby (ed.), Oxford Classical Texts, Oxford, Oxford University Press.

Séneca, Lucio Anneo (1982): Medea, V. García Yebra (trad. e introd.), Madrid, Gredos.

Virgilio Marón, Publio (1969): Opera, R. A. B. Mynors (ed.), Oxford Classical Texts, Oxford, Oxford University Press.

Virgilio Marón, Publio (2000 [1555]): La Eneida, traducida por Gregorio Hernández de Velasco, Virgilio Bejarano (ed.), Barcelona Planeta.

Virgilio Marón, Publio (2003): Obras Completas, Aurelio Espinosa Pólit, Arturo Soler Ruiz y Pollux Hernúñez (eds. y trads.), Madrid, Cátedra.

\section{BIBLIOGRAFÍA}

Alarcos Martínez, Miguel (2011): "Casos de contaminatio entre Heliodoro y Virgilio en el Persiles: problemática y generalidades", en Perfiles de Grecia y Roma (Actas del XII Congreso de la SEEC), II, Madrid, Estudios Clásicos, pp. 315-322.

Alarcos Martínez, Miguel (2012): "El influjo de Virgilio en Libro II del Persiles: situaciones argumentales y personajes", en Dulces Camenae: Poética y Poesía latinas, II, Granada, Editorial Universidad de Granada, pp. 1195-1208.

Armstrong-Roche, Michael (2009): Cervantes' Epic Novel: Empire, Religion, and the Dream Life of Heroes in Persiles, Toronto-Buffalo-London, University of Toronto Press.

Barnés Vázquez, Antonio y Jean Canavaggio (2009): "Yo he leído en Virgilio": la tradición clásica en el Quijote, Vigo, Academia del Hispanismo.

Blecua, Alberto (2006): "Virgilio en España en los siglos XVI y XVII", en Signos viejos y nuevos: Estudios de historia literaria, Barcelona, Crítica, pp. 155-174.

Gómez Espelosín, Francisco Javier (2005): El descubrimiento del mundo: geografía y viajeros en la antigua Grecia, Madrid, Ediciones Akal.

Lozano Renieblas, Isabel (1998): Cervantes y el mundo del Persiles, Alcalá de Henares, Centro de Estudios Cervantinos.

Schevill, Rudolph (1906a): "Studies in Cervantes. Persiles y Sigismunda. I. Introduction", Modern Philology, IV, pp. 1-24.

Schevill, Rudolph (1906b): "Studies in Cervantes. Persiles y Sigismunda. II. The Question of Heliodorus", Modern Philology, IV, pp. 677-704.

Schevill, Rudolph (1908): "Studies in Cervantes. Persiles y Sigismunda. III. Virgil's and Aeneid", Transactions of the Connecticut Academy of Arts and Sciences, 13, pp. 475-548.

Stegmann, Tilbert Diego (1971): Cervantes' Musterroman "Persiles", Epentheorie und Romanpraxis um 1600, Hamburg, Hartmut Lüdke Verlag.

Fecha de recepción: 1 de julio de 2013

Fecha de aceptación: 25 de octubre de 2013 